\title{
HORSE PERSULANE MANAGEMENT IN COTTON BY ALLELOPATHIC CROP WATER EXTRACTS ALONG WITH REDUCED DOSES OF HERBICIDES
}

\author{
M. Luqman, M. Musa* , M.S. Iqbal, M. Arshad and H.S. Rehman \\ Ayub Agricultural Research Institute, Faisalabad, Pakistan
}

\begin{abstract}
The experiment was conducted at the field of University of Agriculture, Faisalabad, Pakistan to evaluate the performance of lower dose of herbicides in combination with allelopathic crop water leachates for controlling horse persulane (Trianthemaportulacastrum L.) weed in cotton field during two consecutive years of 2007 and 2008. Seven treatments viz., $T_{1}=$ control as weedy, $T_{2}=$ Pendimethalin @ $1.25 \mathrm{~kg}$ active ingredient (a.i.) ha ${ }^{-1}$ (full dose) as pre-emergence, $\mathrm{T}_{3}=$ Paraquat @ $200 \mathrm{~g}$ a.i. ha ${ }^{-1}$ (full dose) direct shielded at 40 days after sowing (DAS), $\mathrm{T}_{4}=$ Pendimethalin @ $0.417 \mathrm{~kg}$ a.i. ha ${ }^{-1}(1 / 3$ dose $)$ as pre-emergence, $\mathrm{T}_{5}=$ Paraquat @ 67g a.i. ha ${ }^{-1}(1 / 3$ dose) direct shielded at 40 DAS, $\mathrm{T}_{6}=$ sorghum + sunflower + brassica + mulberry water extracts each @ 18 I ha ${ }^{-1}+$ Pendimethalin @ $0.417 \mathrm{~kg}$ a.i. ha ${ }^{-1}(1 / 3$ dose $)$ as pre-emergence, and $T_{7}=$ sorghum + sunflower + brassica + mulberry water extracts each @ 18 । ha ${ }^{-1}$ + Paraquat @ 67g a.i. ha ${ }^{-1}(1 / 3$ dose) direct shielded at 40 DAS were compared. Combination of water leachates of allelopathic crops with either $1 / 3$ dose of Paraquat or with $1 / 3$ dose of Pendimethalin were found more effective than other treatments for reducing density and dry weight of horse persulane at both the stages. Higher but identical number of bolls per plant, boll weight per plant and seed cotton yield were recorded in water leachates $+1 / 3$ dose of Pendimethalin as pre-emergence, and water leachates $+1 / 3$ dose of Paraquat direct shielded at 40 DAS. Higher gross return and gross margin were also obtained from the same treatments. The results revealed that sorghum, sunflower, brassica and mulberry water extracts each @ 18 ha $^{-1}$ in combination with $1 / 3$ dose of Paraquat direct shielded at 40 DAS or with $1 / 3$ dose of Pendimethalin as pre-emergence is economical, environment friendly and sustainable strategy for controlling horse persulane weed in cotton field in Pakistan.
\end{abstract}

Keywords: Allelopathic crop water extracts, cotton, horse persulane, paraquat, pendimethalin and water leachates.

* Corresponding author email: mum96@hotmail.com

Received: 25.05.2017 
M. Musa et al.

\section{INTRODUCTION}

Cotton is the main fiber crop in Pakistan. It plays a significant role in economy of the country. Share of cotton in value addition in agriculture accounts for $8.6 \%$ and that in GDP is $1.8 \%$. Based on area of cotton, Pakistan ranks $5^{\text {th }}$ in the world while in production, it ranks $3^{\text {rd }}$ position (Economic Survey of Pakistan, 2006). The average yield of cotton in Pakistan is much lower than potential yield. The yield gap among research farms, progressive farmers and common farmers is primarily due to lack in adoption of advanced management practices specially plant protection. Plant protection and weed management are the most neglected components, which result in yield loss up to 20-40\% in different crops (Rehman et al., 2013). Chemical weed control is an efficient and effective method, and widely practiced in all crops especially in cotton. Although herbicides are effective tool for weed control yet certain limitations confront their use. Specific knowledge is needed for their use, which is lacking in Pakistan. It is due to unawareness and limited trained manpower (Rehman et al., 2013). Sometimes, selection of improper herbicide leads to create resistance in weeds, and weeds remain uncontrolled. Moreover, herbicides may pollute soil and water. So, it is a dire need to find out new environment friendly techniques and methods for controlling weeds. One possible option may be the reduction of herbicide usage. Another possibility is to develop natural products, bioherbicides and utilizing allelopathic crop water leachates as foliar spray or combined application of these leachates with lower doses of the recommended herbicides. They are effective, economical, viable and environment friendly. There are two fundamental approaches to use natural products for weed management. First one is to use them as allelochemicals in crops or cover crops to manage weeds, insects, pests and pathogens (Duke et al., 2002).The other strategy is to use them directly as herbicides in the form of crop water leachates. Use of sorgaab (sorghum water leachate) as natural weed inhibitor in maize has been suggested by Ahmad et al. (1995). Cheema et al. (2003) stated that sorgaab reduces density as well as dry weight of horse persulane weed and thereby increased maize yield by 13-37\%.

Similarly, Singh et al. (2003) reported that weeds cause enormous loss of crop yield by interfering agro-ecosystems. Worldwide efforts are being made to reduce the usage of synthetic herbicides for weed control. So, the use of allelochemical is an alternative environment friendly method of weed control in all crops. The crops possessing allelopathic potential should be included in crop rotation, or use them as cover crop, smother crop, green manures, or intercropped for sustainable weed management. However, literature regarding allelopathic weed control in Pakistan is meager. Hence, this experiment was conducted to evaluate the performance of lower dose of herbicides in combination with allelopathic crop water leachates for controlling horse persulane weed in cotton field. 


\section{MATERIALS AND METHODS}

A field experiment was undertaken at the University of Agriculture, Faisalabad, Pakistan on loamy soil having moderate fertility during two consecutive years of 2007 and 2008 to determine suitable combination of sorghum (Sorghum bicolor L.), sunflower (Helianthus annuus L.), mulberry (Morusalba L.) and Brassica (Brassica spp.) water extracts @ $181 \mathrm{ha}^{-1}$ with reduced doses of Paraquat (Gramoxon 20 SL), and Pendimethalin (Stomp 330 E) for weed management in cotton. The experiment was laid out in Randomized Complete Block Design with four replications having a net plot size of $7 \mathrm{~m} \mathrm{x} 3 \mathrm{~m}$. Seven treatments were: $\mathrm{T}_{1}=$ control as weedy, $\mathrm{T}_{2}=$ Pendimethalin @ $1.25 \mathrm{~kg}$ active ingredient (a.i.) ha ${ }^{-1}$ (full dose) as preemergence, $\mathrm{T}_{3}=$ Paraquat @ $200 \mathrm{~g}$ a.i. $\mathrm{ha}^{-1}$ (full dose) direct shielded at 40 days after sowing (DAS), $\mathrm{T}_{4}=$ Pendimethalin @ $0.417 \mathrm{~kg}$ a.i. $\mathrm{ha}^{-1}(1 / 3$ dose $)$ as pre-emergence, $\mathrm{T}_{5}=$ Paraquat @67g a.i. ha ${ }^{-1}(1 / 3$ dose $)$ direct shielded at $40 \mathrm{DAS}, \mathrm{T}_{6}=$ sorghum + sunflower + brassica + mulberry water extracts each@181 ha ${ }^{-1}+$ Pendimethalin@ $0.417 \mathrm{~kg}$ a.i. ha ${ }^{-1}(1 / 3$ dose $)$ as pre-emergence, and $\mathrm{T}_{7}=$ sorghum + sunflower + brassica + mulberry water extracts each @ 181 ha $^{-1}+$ Paraquat @ 67g a.i. ha ${ }^{-1}(1 / 3$ dose) direct shielded at 40 DAS were compared.

Crop herbage (sorghum, sunflower, brassica and mulberry) was harvested at maturity, dried under shade and then chopped into $2 \mathrm{~cm}$ pieces with the help of fodder cutter. This chopped material was soaked in distilled water with a ratio of 1:10 $(\mathrm{w} / \mathrm{v})$ for 24 hours. Water extracts were collected by passing through sieves. The filtrate was boiled at $100^{\circ} \mathrm{C}$ for reducing the volume by 20 times (Cheema and Khaliq, 2000).

Cotton cultivar MNH-786 was sown on a well prepared seedbed in $75 \mathrm{~cm}$ spaced rows with single row hand drill on5 May 2007 and 12 May 2008, using $15 \mathrm{~kg}$ $\mathrm{ha}^{-1}$ delinted seed. Thinning was done to maintain $30 \mathrm{~cm}$ plant to plant distance. Fertilizer@125-57-23 NPK kg ha ${ }^{-1}$ was applied during both the years. Half of nitrogen with full doses of phosphorous and potassium was applied at the time of sowing, while the remaining half of nitrogen was applied followed by first irrigation. First irrigation was given at 35 DAS and subsequent irrigations were adjusted according to the climatic conditions and need of the crop. The crop was harvested at maturity stage.

Data on weed density and weed dry weight were taken at 40 and 60 DAS. Germination count was performed after emergence of the crop. Leaf area per plant was taken from randomly collected three plants from each plot at 90 and 120 DAS. Plant height, number of monopodial and sympodial branches per plant, number and weight of bolls per plant were collected at maturity stage. Seed cotton yield was taken from whole plot. Ginning out turn (GOT) was calculated by using the following formula: 


$$
\text { GOT } \%=\frac{\text { Weight of lint }}{\text { Weight of seed cotton }} \times 100
$$

Economic analyses were performed based on the cost occurred for weed control practices in different treatments.

The trend of data collected during both the years was found similar. So, the data were averaged. The average data were analyzed statistically and differences among the treatment means were compared by using the Least Significant Difference (LSD) test at 0.05 probability level with the help of M-Stat C programme.

\section{RESULTS AND DISCUSSION}

\section{A. Horse persulane density and dry matter weight}

Density of horse persulane was high at 40 DAS and then declined at 60 DAS in all treatments (Table 1). Pendimethalin suppressed the weed by $47.2,56.8$ and $66.4 \%$ at 40 DAS and 47.0, 63.6 and $62.1 \%$ at 60 DAS when applied at the rate of $1 / 3$ dose, full dose and $1 / 3$ dose with leachates, respectively. But Paraquat suppressed the weeds by $9.6,13.6$ and $19.2 \%$ at 40 DAS and $34.9,39.4$ and $40.9 \%$ at 60 DAS when applied at the rate of $1 / 3$ dose, full dose and $1 / 3$ dose with leachates, respectively. These results indicated that weed suppression by Pendimethalin with water leachates was more than those of Paraquat with water leachates at both the stages. This was because of pre-emergence application of Pendimethalin which killed most of the weeds at early stages. Weed mortality with Paraquat as post-emergence spray was comparatively lower. These results are partially similar to the findings of Cheema et al. (2000a) who reported that Pendimethalin dose could be reduced to $67 \%$ in combination with Sorgaab.

Weed dry weight at 40 DAS was morethan at 60 DAS when Paraquat was applied. But at 60 DAS, higher dry weight with less density was observed when Pendimethalin was applied owing to less intra specific competition (Table 1). However, dry weight reduction of weeds in Paraquat treatments at 60 DAS was 58.4, 85.0 and $86.1 \%$ as against to $32.1,49.4$ and $63.3 \%$ in Pendimethalin when applied at $1 / 3$ dose, full dose and $1 / 3$ dose with water leachates, respectively. These results partially support the findings of Cheema et al. (2003a) who suggested that $67 \%$ reduction in Pendimethalin dose in combination with allelopathic crop water leachates is very effective to suppress weeds flora in wheat. While findings regarding Paraquat and allelopathic crop water leachates are encouraging and in line with the work of Cheema et al. (2003b) who suggested that allelopathic crop water leachates in combination with lower herbicides rate could be used for weed control in cotton. 
Table 1. Effect of combined application of allelopathic crop water leachates and lower herbicide rates on density and dry weight of horse persulane

\begin{tabular}{|l|c|c|c|c|}
\hline \multirow{2}{*}{ Treatment } & \multicolumn{2}{|c|}{ Weed density $\left(\mathrm{no.}^{-2}\right)$} & \multicolumn{2}{c|}{ Weed dry weight $\left(\mathrm{g} \mathrm{m}^{-2}\right)$} \\
\cline { 2 - 5 } & 40 DAS & 60 DAS & 40 DAS & 60 DAS \\
\hline $\mathrm{T}_{1}$ & 125 & 66 & 320 & 1190 \\
\hline $\mathrm{T}_{2}$ & 54 & 24 & 227 & 602 \\
& $(-56.8)$ & $(-63.6)$ & $(-29.1)$ & $(-49.4)$ \\
\hline $\mathrm{T}_{3}$ & 108 & 40 & 283 & 178 \\
& $(-13.6)$ & $(-39.4)$ & $(-11.6)$ & $(-85.0)$ \\
\hline $\mathrm{T}_{4}$ & 66 & 35 & 249 & 808 \\
& $(-47.2)$ & $(-47.0)$ & $(-22.2)$ & $(-32.1)$ \\
\hline $\mathrm{T}_{5}$ & 113 & 43 & 286 & 496 \\
& $(-09.6)$ & $(-34.8)$ & $(-10.6)$ & $(-58.4)$ \\
\hline $\mathrm{T}_{6}$ & 42 & 25 & 210 & 437 \\
& $(-66.4)$ & $(-62.1)$ & $(-34.4)$ & $(-63.3)$ \\
\hline $\mathrm{T}_{7}$ & 101 & 39 & 266 & 166 \\
& $(-19.2)$ & $(-40.9)$ & $(-16.9)$ & $(-86.1)$ \\
\hline $\mathrm{LSD}_{(0.05)}$ & 9.23 & 6.86 & 34.8 & 20.7 \\
\hline
\end{tabular}

*Figures within parenthesis indicate $\%$ decrease (-) or increase $(+)$ over control

$\mathrm{T}_{1}=$ control as weedy, $\mathrm{T}_{2}=$ Pendimethalin @ $1.25 \mathrm{~kg}$ active ingredient (a.i.) ha ${ }^{-1}$ (full dose) as preemergence, $\mathrm{T}_{3}=$ Paraquat @ $200 \mathrm{~g}$ a.i. ha ${ }^{-1}$ (full dose) direct shielded at 40 days after sowing $(\mathrm{DAS}), \mathrm{T}_{4}=$ Pendimethalin @ $0.417 \mathrm{~kg}$ a.i. ha ${ }^{-1}(1 / 3$ dose $)$ as pre-emergence, $\mathrm{T}_{5}=$ Paraquat @ $67 \mathrm{~g}$ a.i. ha ${ }^{-1}(1 / 3$ dose $)$ direct shielded at $40 \mathrm{DAS}, \mathrm{T}_{6}=$ sorghum + sunflower + brassica + mulberry water extracts each @ 181 $\mathrm{ha}^{-1}+$ Pendimethalin @ $0.417 \mathrm{~kg}$ a.i. $\mathrm{ha}^{-1}(1 / 3$ dose $)$ as pre-emergence, and $\mathrm{T}_{7}=$ sorghum + sunflower + brassica + mulberry water extracts each @ 181 ha $^{-1}+$ Paraquat @ $67 \mathrm{~g}$ a.i. ha ${ }^{-1}(1 / 3$ dose $)$ direct shielded at 40 DAS

\section{B. Cotton}

Germination remained unaffected among the treatments (Table 2). These results are against the findings of Vasilakoglou et al. (2005) who reported the positive effect of allopathic water extracts on germination of cotton.

Cotton plant height was significantly more in all treatments than control and the tallest plants were observed in $\mathrm{T}_{7}$ and $\mathrm{T}_{6}$ treatments which were statistically at par with each other (Table 2). Similar observations were reported by Cheema et al. (2000) who reported that when weeds were managed, plant height of cotton crop was more as compared to weeds infested crop.

Number of monopodial and sympodial branches was similar to those of plant height showing that taller plants had more number of branches (Table 2). More branchingin taller plant was observed due to better weed control. These results 
confirmed the findings of Cheema et al. (2000b) who stated that both monopodial and sympodial branches increased with weed suppression in cotton.

Table 2. Effect of combined application of allelopathic crop water leachates and lower herbicide rates on cotton germination, plant height and branches of cotton

\begin{tabular}{|l|c|c|c|c|}
\hline Treatment & $\begin{array}{c}\text { Germination } \\
\left(\mathrm{m}^{-2}\right)\end{array}$ & $\begin{array}{c}\text { Pant height } \\
(\mathrm{cm})\end{array}$ & \multicolumn{2}{|c|}{$\begin{array}{c}\text { No. of Branches } \\
\left(\mathrm{plant}^{-1}\right)\end{array}$} \\
\hline & & & Monopodial & Sympodial \\
\hline $\mathrm{T}_{1}$ & 6.25 & 90.0 & 3.30 & 14.8 \\
\hline $\mathrm{T}_{2}$ & 5.75 & 100.6 & 3.34 & 19.2 \\
\hline $\mathrm{T}_{3}$ & 5.68 & 101.0 & 4.05 & 23.6 \\
\hline $\mathrm{T}_{4}$ & 5.63 & 100.0 & 3.30 & 18.9 \\
\hline $\mathrm{T}_{5}$ & 5.50 & 97.1 & 3.30 & 18.2 \\
\hline $\mathrm{T}_{6}$ & 5.37 & 103.8 & 4.50 & 26.8 \\
\hline $\mathrm{T}_{7}$ & 5.38 & 105.0 & 4.23 & 25.8 \\
\hline $\mathrm{LSD}_{(0.05)}$ & $\mathrm{NS}$ & 4.09 & 0.330 & 1.99 \\
\hline
\end{tabular}

*NS $=$ Non-significant

$\mathrm{T}_{1}=$ control as weedy, $\mathrm{T}_{2}=$ Pendimethalin @ $1.25 \mathrm{~kg}$ active ingredient (a.i.) ha ${ }^{-1}$ (full dose) as preemergence, $\mathrm{T}_{3}=$ Paraquat @ $200 \mathrm{~g}$ a.i. ha ${ }^{-1}$ (full dose) direct shielded at 40 days after sowing (DAS), $\mathrm{T}_{4}=$ Pendimethalin @ $0.417 \mathrm{~kg}$ a.i. ha ${ }^{-1}(1 / 3$ dose $)$ as pre-emergence, $\mathrm{T}_{5}=$ Paraquat @ $67 \mathrm{~g}$ a.i. ha ${ }^{-1}(1 / 3$ dose $)$ direct shielded at $40 \mathrm{DAS}, \mathrm{T}_{6}=$ sorghum + sunflower + brassica + mulberry water extracts each @ 181 $\mathrm{ha}^{-1}+$ Pendimethalin@ $0.417 \mathrm{~kg}$ a.i. ha ${ }^{-1}(1 / 3$ dose $)$ as pre-emergence, and $\mathrm{T}_{7}=$ sorghum + sunflower + brassica + mulberry water extracts each @ $181 \mathrm{ha}^{-1}+$ Paraquat @ $67 \mathrm{~g}$ a.i. ha ${ }^{-1}(1 / 3$ dose $)$ direct shielded at 40 DAS

Maximum number of bolls per plant were recorded in $\mathrm{T}_{6}$ (30.6) and $\mathrm{T}_{7}$ (29.3) treatments (Table 3). These treatments were statistically at par with each other but significantly higher than other treatments. More number of bolls per plant resulted in increase of boll weight per plant in these treatments (Table 3). Increase in number of bolls and boll weight per plant was possibly due to better weed management. These results supported the findings reported by Cheema et al. (2000b) who narrated that sorgaab, sorghum mulch and herbicidal treatments significantly influenced the number of bolls and boll weight per plant due to better weed control.

Maximum leaf area at both stages $\left(515.3 \mathrm{~cm}^{2}\right.$ at 90 DAS and $559.3 \mathrm{~cm}^{2}$ at 120 DAS) was recorded in $\mathrm{T}_{7}$ treatment. But in other treatments, leaf area at both stages was similar (Table 3).

Seed cotton yield varied significantly due to different weed management treatments (Table 4). The increase in seed cotton yield over control ranged from 
$48.6 \%$ to $97.5 \%$. Maximum seed cotton yield $\left(2305 \mathrm{~kg} \mathrm{ha}^{-1}\right)$ was observed in $\mathrm{T}_{7}$ treatment and it was statistically identical to $\mathrm{T}_{6}$ treatment $\left(2276 \mathrm{~kg} \mathrm{ha}^{-1}\right)$. The reason for higher seed cotton yield in those treatments was due to more number of bolls and boll weight per plant. Almost similar effects of allelopathic crop water leachates on seed cotton yield were observed by Cheema et al. (2002) who demonstrated that combination of allelopathic crop water leachates and 1/3 dose of Paraquat increased seed cotton yield.

Table 3. Effect of combined application of allelopathic crop water leachates and lower herbicide rates on bolls, boll weight and leaf area of cotton

\begin{tabular}{|l|c|c|c|c|}
\hline Treatment & \multirow{2}{*}{$\begin{array}{c}\text { No. of Bolls } \\
\text { (plant }\end{array}$} & \multirow{2}{*}{$\begin{array}{c}\text { Boll weight } \\
\text { (g plant }\end{array}$} & & \multicolumn{2}{|c|}{$\begin{array}{c}\text { Leaf area } \\
\left(\mathrm{cm}^{2}\right)\end{array}$} \\
\cline { 4 - 5 } & & & $90 \mathrm{DAS}$ & $120 \mathrm{DAS}$ \\
\hline $\mathrm{T}_{1}$ & 18.4 & 55.9 & 444.4 & 459.5 \\
\hline $\mathrm{T}_{2}$ & 26.8 & 106.6 & 446.0 & 495.4 \\
\hline $\mathrm{T}_{3}$ & 27.8 & 119.0 & 467.6 & 510.0 \\
\hline $\mathrm{T}_{4}$ & 22.9 & 82.9 & 443.0 & 448.4 \\
\hline $\mathrm{T}_{5}$ & 21.5 & 71.3 & 459.4 & 475.6 \\
\hline $\mathrm{T}_{6}$ & 30.6 & 129.7 & 469.5 & 510.1 \\
\hline $\mathrm{T}_{7}$ & 29.3 & 132.6 & 514.3 & 559.3 \\
\hline $\mathrm{LSD}_{(0.05)}$ & 2.14 & 14.24 & 15.11 & 19.51 \\
\hline
\end{tabular}

$\mathrm{T}_{1}=$ control as weedy, $\mathrm{T}_{2}=$ Pendimethalin @ $1.25 \mathrm{~kg}$ active ingredient (a.i.) ha ${ }^{-1}$ (full dose) as preemergence, $\mathrm{T}_{3}=$ Paraquat @ $200 \mathrm{~g}$ a.i. $\mathrm{ha}^{-1}$ (full dose) direct shielded at 40 days after sowing (DAS), $\mathrm{T}_{4}=$ Pendimethalin @ $0.417 \mathrm{~kg}$ a.i. ha ${ }^{-1}(1 / 3$ dose $)$ as pre-emergence, $\mathrm{T}_{5}=$ Paraquat @ $67 \mathrm{~g}$ a.i. ha ${ }^{-1}(1 / 3$ dose $)$ direct shielded at $40 \mathrm{DAS}, \mathrm{T}_{6}=$ sorghum + sunflower + brassica + mulberry water extracts each @ 181 $\mathrm{ha}^{-1}+$ Pendimethalin@ $0.417 \mathrm{~kg}$ a.i. ha ${ }^{-1}(1 / 3$ dose $)$ as pre-emergence, and $\mathrm{T}_{7}=$ sorghum + sunflower + brassica + mulberry water extracts each @ 181 ha $^{-1}+$ Paraquat @ $67 \mathrm{~g}$ a.i. ha ${ }^{-1}(1 / 3$ dose $)$ direct shielded at 40 DAS

Ginning out turn (GOT) was not affected by any of the treatments (Table 3). Similar findings were reported by Cheema et al. (2000b) who found no effect on GOT\% by different weed control practices. This behavior is due to the genetic potential of variety.

\section{Economic analysis}

Gross return increased with increasing seed cotton yield and the highest gross return (US\$ $864.375 \mathrm{ha}^{-1}$ ) was recorded in $\mathrm{T}_{7}$ treatment which was close to T6 treatment (US\$ $853.500 \mathrm{ha}^{-1}$ ). Weed control cost includes herbicide cost, extract cost, sprayer rent and labour cost. Weed control cost was maximum (US\$5.15 ha ${ }^{-1}$ ) in $\mathrm{T}_{7}$ and it was very close to $\mathrm{T}_{6}$ (US\$ $5.12 \mathrm{ha}^{-1}$ ). Gross margin ranged from US $\$ 437.625$ 
to859.225 in different treatments. The highest gross margin was obtained from $\mathrm{T}_{7}$ treatment and it was close to $\mathrm{T}_{6}$ treatment (Table 4). The results indicated that $\mathrm{T}_{7}$ and $\mathrm{T}_{6}$ treatments were more profitable than other weed management treatments.

Table 4. Effect of combined application of allelopathic crop water leachates andlower herbicide rates on seed cotton yield, ginning out turn (GOT) and economics

\begin{tabular}{|l|c|c|c|c|c|}
\hline Treatment & $\begin{array}{c}\text { Seed cotton } \\
\text { yield } \\
\left(\mathrm{kg} \mathrm{ha}^{-1}\right)\end{array}$ & $\begin{array}{c}\text { GOT } \\
(\%)\end{array}$ & $\begin{array}{c}\text { Gross return** } \\
\left(\mathrm{US} \mathrm{ha}^{-1}\right)\end{array}$ & $\begin{array}{c}\text { Weed control } \\
\text { cost*** } \\
\left(\mathrm{US} \mathrm{h}^{-1}\right)\end{array}$ & $\begin{array}{c}\text { Gross margin } \\
\left({\left.\mathrm{US} \$ \mathrm{ha}^{-1}\right)}^{-1}\right.\end{array}$ \\
\hline $\mathrm{T}_{1}$ & 1167 & 40.1 & 437.625 & 0 & 437.625 \\
\hline $\mathrm{T}_{2}$ & $\begin{array}{c}1831 \\
(56.9)\end{array}$ & 42.3 & 686.625 & 3.04 & 683.585 \\
\hline $\mathrm{T}_{3}$ & $\begin{array}{c}1915 \\
(64.1)\end{array}$ & 41.4 & 718.125 & 3.15 & 714.975 \\
\hline $\mathrm{T}_{4}$ & $\begin{array}{c}1742 \\
(49.4)\end{array}$ & 40.2 & 653.250 & 2.32 & 650.930 \\
\hline $\mathrm{T}_{5}$ & $\begin{array}{c}1734 \\
(48.6)\end{array}$ & 40.2 & 650.250 & 2.35 & 647.900 \\
\hline $\mathrm{T}_{6}$ & $\begin{array}{c}2276 \\
(95.1)\end{array}$ & 41.1 & 853.500 & 5.12 & 848.380 \\
\hline $\mathrm{T}_{7}$ & $\begin{array}{c}2305 \\
(97.5)\end{array}$ & 41.3 & 864.375 & 5.15 & 859.225 \\
\hline $\mathrm{LSD}_{(0.05)}$ & 48.4 & $\mathrm{NS}$ & - & - & - \\
\hline
\end{tabular}

$* \mathrm{NS}=$ Non-significant, $* *$ Market price of seed cotton: US $\$ 0.375 \mathrm{~kg}^{-1}$

*** Weed control cost includes: herbicide cost, extract cost, sprayer rent and labour cost

$\mathrm{T}_{1}=$ control as weedy, $\mathrm{T}_{2}=$ Pendimethalin @ $1.25 \mathrm{~kg}$ active ingredient (a.i.) ha ${ }^{-1}$ (full dose) as preemergence, $\mathrm{T}_{3}=$ Paraquat @ $200 \mathrm{~g}$ a.i. ha ${ }^{-1}$ (full dose) direct shielded at 40 days after sowing (DAS), $\mathrm{T}_{4}=$ Pendimethalin @ $0.417 \mathrm{~kg}$ a.i. ha ${ }^{-1}(1 / 3$ dose $)$ as pre-emergence, $\mathrm{T}_{5}=$ Paraquat @ $67 \mathrm{~g}$ a.i. ha ${ }^{-1}(1 / 3$ dose $)$ direct shielded at 40 DAS, $T_{6}=$ sorghum + sunflower + brassica + mulberry water extracts each @ 181 $\mathrm{ha}^{-1}+$ Pendimethalin @ $0.417 \mathrm{~kg}$ a.i. ha ${ }^{-1}(1 / 3$ dose $)$ as pre-emergence, and $\mathrm{T}_{7}=$ sorghum + sunflower + brassica + mulberry water extracts each @ 181 ha $^{-1}+$ Paraquat @ $67 \mathrm{~g}$ a.i. ha ${ }^{-1}(1 / 3$ dose $)$ direct shielded at 40 DAS

\section{CONCLUSION}

From the study, it might be concluded that combination of sorghum, sunflower, brassica and mulberry water leachates at the rate of $181 \mathrm{ha}^{-1}$ with $1 / 3$ dose of Paraquat at 40 DAS direct shielded or $1 / 3$ dose of Pendimethalin as pre-emergence is highly effective, economical, environment friendly and sustainable strategy for controlling horse persulane weed in cotton field for increasing cotton yield in Pakistan. 


\section{REFERENCES}

Ahmad, S., Rehman, A., Cheema, Z.A., Tanveer, A. and Khaliq, A.1995.Evaluation of some crop residues for their allelopathic effect on germination and growth of cotton and cotton weeds.Pakistan WeedScience Conference, Faisalabad, pp: 63-76.

Economic Survey of Pakistan.2006.Ministry of Food, Agriculture and Livestock, Federal Bureau of Statistics, Islamabad.

Cheema,Z.A., Asim, M. and Khaliq, A.2000b.Sorghum allelopathy for weed control in cotton (Gossypiumarborium L.).International Journal Agriculture \&Biology, 2(2): 37-41.

Cheema, Z.A. and Khaliq, A. 2000. Use of sorghum allelopathic properties to control weeds in irrigated wheat in a semi-arid region of Punjab.Agriculture, Ecology \& Environment, 79 (4): 105-112.

Cheema, Z.A., Khaliq, A. and Farooq, R.2003a. Effect of concentrated sorgaab alone and in combination with herbicides and a surfactant in combination with herbicides and a surfactant in wheat. Journal of Animal and Plant Sciences, 13(1): 10-13.

Cheema, Z.A., Khaliq, A. and Hussain, A.R. 2003b.Reducing herbicide rate in combination with allelopathicsorgaab for weed control in cotton. International Journal of Agriculture and Biology, 5(2): 1560-1565.

Cheema, Z.A., Khaliq, A. and Tariq, M.2002.Evaluation of concentrated Sorgaab alone in combination with reduced rates of three pre-emergence herbicides for weed control in cotton (Gossypiumhirsutum L.). International Journal of Agriculture and Biology, 7(3): (549-552).

Cheema, Z.A., Sadiq, H.M.I. and Khaliq, A. 2000a.Efficacy of sorgaab (sorghum water extract) as a natural weed inhibitor in wheat. Pakistan Journal of Agriculture and Biology, 4(2): 144-146.

Duke, S.O., Rimando, A.M., Baerson, S.R., Scheffler, B.E., Ota, E. and Belz, R.G. 2002. Strategies for the use of natural products for weed management. Journal of Pesticide Science, 27: 298-306.

Rehman, M., Ishaque, M., Abbas, G. and Khokhar, M.B. 2013.Evaluation of combined application of allelopathic crop leachates and post emergence herbicide for control of weeds in rice (Oryza sativa L.). Crop Science International (Lahore), 915-920

Singh, H.P., Batish, D.R., Kaur, S., Setia, N. and Kohil, R.K. 2003.Effect of 2benzoxazolinone on the germination, early growth and morphogenic response of mung bean.Journal of Agriculture and Biology, 147 (10): 267-274

Vasilakoglou, I., Dhima, K. and Elefthrohorinos, I. 2005.Allelopathic potential of Bermuda grass and Johnson grass and their interference with cotton and corn. Agronomy Journal, 97(12): 303-313 